\title{
Pancreatic Cancer by AJCC v8 Stage
}

National Cancer Institute

\section{Source}

National Cancer Institute. Pancreatic Cancer by AJCC v8 Stage. NCI Thesaurus. Code C134909.

A term that refers to the staging of exocrine pancreatic cancer according to the American Joint Committee on Cancer, 8th edition. This staging system applies to pancreatic ductal adenocarcinoma, acinar cell carcinoma, intraductal papillary mucinous neoplasm with associated invasive carcinoma, intraductal tubulopapillary neoplasm with associated invasive carcinoma, colloid carcinoma, mucinous cystic neoplasm with associated invasive carcinoma, solid pseudopapillary neoplasm, large cell neuroendocrine carcinoma, small cell neuroendocrine carcinoma, and pancreatoblastoma. Welldifferentiated neuroendocrine tumors are not staged using this staging system. (from AJCC 8th Ed.) 